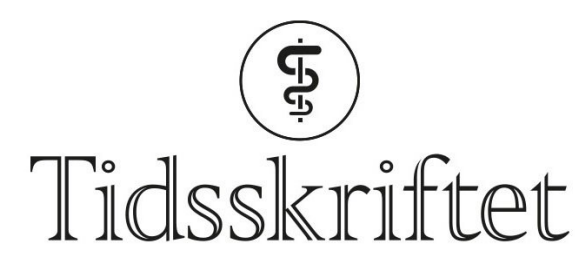

DEN NORSKE LEGEFORENING

\title{
Registrere, lære og forbedre
}

MINILEDER

\section{ARE BREAN}

Sjefredaktør

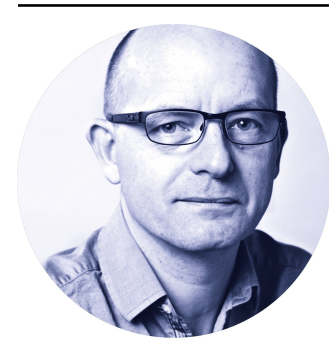

Våre 51 nasjonale medisinske kvalitetsregistre er uttrykk for det aller beste fra evidensbasert medisin. Arbeidet med registrene er en nasjonal dugnad for å registrere alle sider ved en diagnose, behandling og forløp, med siktemål om å endre metodene når resultatene ikke er gode nok. Slik kan man sikre at behandlingen som gis, bygger på samvittighetsfull registrering av resultater, etterfulgt av kritisk evaluering og læring.

Takket være et engasjert fagmiljø og penger fra Kreftforeningen etableres nå Nasjonalt kvalitetsregister for pankreaskreft som Norges 52 . medisinske kvalitetsregister. Det er paradoksalt at det har tatt så lang tid å få på plass akkurat dette registeret. Pankreaskreft er en av våre mest dødelige kreftformer. Flere dør årlig av pankreaskreft enn av brystkreft i Norge, symptombyrden for pasienter og pårørende er stor og det har vært få behandlingsfremskritt de siste tiårene. Endelig får man nå en systematisk nasjonal dokumentasjon av alle sider ved sykdommen. Det gir håp om mer oppmerksomhet, mer ressurser og bedret kurativt og palliativt tilbud også til denne pasientgruppen.

Publisert: 26. oktober 2020. Tidsskr Nor Legeforen. DOI: 10.4045/tidsskr.20.15.01

(C) Tidsskrift for Den norske legeforening 2020. Lastet ned fra tidsskriftet.no 